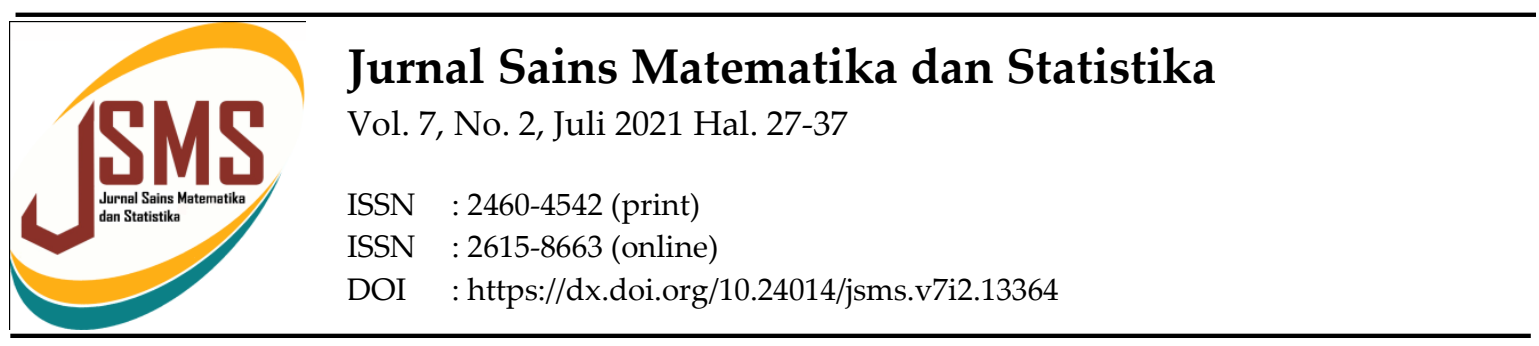

\title{
Pendistribusian Penjualan Beras Menggunakan Best Candidate Method Dan Modi
}

\author{
Sri Basriati ${ }^{1}$, Elfira Safitri ${ }^{2}$, Ayu Octariana ${ }^{3}$ \\ 1,2 Jurusan Matematika, UIN Sultan Syarif Kasim Riau \\ Jl. HR. Soebrantas No. 155 Simpang Baru, Panam, Pekanbaru, 28293 \\ ${ }^{3}$ Jurusan Matematika, UIN Suska Riau
}

Jl. HR Soebrantas KM 12,5, Kampus Bina Widya Simpang Baru, Pekanbaru, 28293

Email:, sribasriati@uin-suska.ac.id ${ }^{1}$, elfira.safitri@uin-suska.ac.id ${ }^{2}$, ayuoctariana98@gmail.com $^{3}$

\begin{abstract}
Abstrak
Toko Empat Saudara Pekanbaru merupakan salah satu toko yang bergerak dalam bidang pendistribusian beras. Pendistribusian beras harus mengalokasian sedemikian rupa karena terdapat perbedaan biaya transportasi dari suatu sumber ke tujuan yang berbeda. Model transportasi merupakan pendistribusian suatu barang dari suatu sumber (supply) ke tujuan (demand) bertujuan untuk mengoptimalkan jumlah pengiriman ke tujuan dalam sekali pengiriman, sehingga dapat menekan biaya serendah mungkin. Adapun metode yang digunakan pada penelitian ini adalah Best Candidate Method. Best Candidate Method merupakan metode untuk mencari solusi layak awal minimum biaya transportasi dengan cara membandingkan total ongkos antara kombinasi satu dengan kombinasi lainnya. Selanjutnya, solusi optimal akan ditentukan menggunakan metode MODI. Adapun tujuan dari penelitian ini adalah untuk mendapatkan solusi layak awal minimum biaya pendistribusian penjualan beras di Toko Empat Saudara menggunakan Best Candidate Method. Berdasarkan hasil penelitian pendistribusian beras di Toko Empat Saudara Pekanbaru menggunakan Best Candidate Method menghasilkan solusi belum optimal dengan biaya Rp. 996.566 setelah dilakukan pengecekkan menggunakan metode MODI mengahasilkan solusi optimal Rp. 976.665.
\end{abstract}

Kata Kunci: Best Candidate Method, Modified Distribution, Pendistribusian Beras

\begin{abstract}
Four Brothers Store Pekanbaru is one of the shops engaged in the distribution of rice. The distribution of rice must be allocated in such a way because there are differences in transportation costs from one source to different destinations. The transportation model is the distribution of an item from a source (supply) to a destination (demand) aiming to optimize the number of shipments to the destination in one shipment, so as to reduce costs as low as possible. The method used in this study is the Best Candidate Method. The Best Candidate Method is a method to find a feasible solution for the minimum initial cost of transportation by comparing the total cost between one combination and another. Next, the optimal solution will be determined using the MODI method. The purpose of this study is to obtain a feasible solution for the minimum initial cost of
\end{abstract}


distributing rice sales at the Empat Saudara Store using the Best Candidate Method. Based on the results of the research on the distribution of rice at the Empat Saudara Store Pekanbaru using the Best Candidate Method, the solution was not optimal at a cost of Rp. 996,566 after checking using the MODI method resulted in an optimal solution of Rp. 976,665.

Keywords: Best Candidate Method, Modified Distribution, Distribution of Rice

\section{Pendahuluan}

Indonesia terdiri dari beberapa sektor pertanian rakyat (sub sektor tanaman pangan), sub sektor perkebunan, sub sektor pertenakan, sub sektor perhutanan, dan sub sektor perikanan. Tanaman padi termasuk dalam sub sektor tanaman pangan dalam sektor pertanian. Padi sangat bermanfaat bagi kehidupan manusia, di Indonesia beras merupakan makanan pokok dan juga makanan mengandung karbohidrat. Beras yang telah dihasilkan akan didistribusikan ke berbagai daerah.

Pendistribusian beras dapat dihitung dengan ilmu matematika untuk mecari solusi optimalnya. Ilmu matematika metode yang menjadi pemecah masalah untuk mendapatkan solusi optimal yaitu model transportasi. Model transportasi adalah suatu metode yang digunakan untuk mengatur distribusi dari sumber-sumber yang menyediakan produk-produk yang sama di tempat- tempat yang membutuhkan secara optimal.

Salah satu metode yang digunakan dalam penyelesaian model transportasi adalah Best Candidate Method. Best Candidate Method menghasilkan solusi layak awal dengan total ongkos terkecil dengan cara membandingkan total ongkos antara kombinasi satu dengan kombinasi yang lainnya. Penelitian terkait mengenai Best Candidate Method adalah penelitian Wulan [9] pada tahun 2017 yang berjudul "Penggunaan Best Candidates Method Untuk Mendapatkan Solusi Layak Awal" yang menjelaskan konsep dan langkah kerja Best Candidate Method serta mengetahui hasil solusi awal model transportasi. Selanjutnya penelitian Ahmad [1] pada tahun 2012 yang berjudul "The Best Candidates Method for Solving Optimazation Problems yang menjelaskan konsep dan langkah kerja Hungarian dan Best Candidate Method".

Berdasarkan penelitian sebelumnya, penulis ingin melakukan penelitian tentang penentuan rute pendistribusian beras di Toko Empat Saudara menggunakan Best Candidate Method. Adapun tujuan dari penelitian ini adalah untuk mendapatkan solusi layak awal minimum biaya pendistribusian penjualan beras di Toko Empat Saudara menggunakan Best Candidate Method.

\section{Metode Penelitian}

Bab ini berisikan tentang metode-metode yang dilakukan agar dapat memperoleh hasil yang dibutuhkan dalam penelitian ini. Metode yang akan dibahas di penelitian ini adalah Best Candidate Method.

\subsection{Landasan Teori}

\subsubsection{Model Transportasi}

Model transportasi merupakan metode yang digunakan untuk mengatur distribusi dari sumber-sumber yang menyediakan produk yang sama ke tempat-tempat yang membutuhkan secara optimal dengan biaya yang termurah. Alokasi produk ini 
harus diatur sedemikian rupa karena terdapat perbedaan biaya-biaya alokasi dari satu sumber atau beberapa sumber ketujuan lain [5].

Model transportasi berkaitan dengan suatu situasi dimana suatu komoditas hendak di kirim sejumlah sources (sumber) menuju ke sejumlah destination (tujuan). Tujuan dari persoalan tersebut adalah menentukan jumlah komoditas yang harus dikirim dari tiap-tiap source ke tiap-tiap destination sedemikian hingga biaya total pengiriman dapat diminimumkan, dan pada saat yang sama pembatas yang berupa keterbatasan pasokan dan kebutuhan permintaan tidak dilanggar. Model transportasi mengansumsikan bahwa biaya pengiriman komoditas pada rute tertentu adalah proposional dengan banyaknya unit komoditas yang dikirimkan pada rute tersebut [2].

Menurut [3], Persoalan Transportasi yaitu, persoalan yang membahas masalah pendistribusian suatu komoditas atau produk dari sejumlah sumber (supply) ke sejumlah tujuan (demand), dengan bertujuan meminimumkan ongkos pengangkutan yang terjadi. Karakteristik khusus persoalan transportasi adalah:

a. Terdapat sejumlah sumber dan sejumlah tujuan tertentu.

b. Kuantitas komoditi atau barang yang akan didistribusikan dari setiap sumber dan yang diminta oleh setiap tujuan, besarnya tertentu.

c. Komoditas yang dikirim atau yang diangkut dari suatu sumber ke suatu tujuan besarnya sesuai dengan permintaan atau kapasitas sumber.

d. Ongkos pengangkutan komoditas dari suatu sumber ke suatu tujuan, besarnya tertentu.

Berikut model umum transportasi:

1. Fungsi tujuan

Minimumkan/Maksimumkan

$$
\begin{aligned}
& Z=C_{11} X_{11}+C_{12} X_{12}+C_{13} X_{13}+\ldots+C_{1 n} X_{1 n}+C_{21} X_{21}+C_{22} X_{22}+C_{23} X_{23}+\cdots \\
& +C_{2 n} X_{2 n}+\ldots+C_{m 1} X_{m 1}+\ldots+C_{m n} X_{m n}
\end{aligned}
$$

2. Fungsi kendala

Persediaan:

$$
\begin{aligned}
& X_{11}+X_{12}+\ldots+X_{1 n}=a_{1} \\
& X_{21}+X_{22}+\ldots+X_{2 n}=a_{2} \\
& \vdots \\
& X_{m 1}+X_{m 2}+\ldots+X_{m n}=a_{n}
\end{aligned}
$$

Permintaan:

$$
\begin{aligned}
& X_{11}+X_{21}+\cdots+X_{m 1}=b_{1} \\
& X_{12}+X_{22}+\ldots+X_{m 2}=b_{2} \\
& \vdots \\
& \ddots \quad \quad \vdots \\
& X_{1 n}+X_{2 n}+\ldots+X_{m n}=b_{n}
\end{aligned}
$$

\subsubsection{Best Candidate Method}

Menurut [9], Best Candidate Method menghasilkan solusi layak awal dengan total ongkos terkecil dengan cara membandingkan total ongkos antara kombinasi yang satu dengan kombinasi yang lain. 
Adapun langkah-langkah Best Candidate Method sebagai berikut:

1. Memeriksa keseimbangan matriks, jika total supply sama dengan total demaind, maka matriks dikatakan seimbang dan dilanjutkan ke langkah kedua. Jika total supply tidak sama dengan total demaind, maka kita menambahkan baris dummy atau kolom dummy yang diperlukan untuk membuat supply dengan demaind. Kemudian biaya transportasi pada baris dummy atau kolom dummy tersebut diisi dengan nilai nol. Unit cost pada baris dummy atau kolom dummy tidak dipilih sebagai kandidat.

2. Memilih dua kandidat tiap-tiap baris, jika terdapat kandidat yang sama nilainya lebih dari satu, maka pilih kandidat yang nilainya sama lebih dari satu tersebut atau pilih nilai kandidat ongkos terkecil pertama dan ongkos terkecil kedua.

3. Mengidentifikasi baris dengan kandidat biaya terkecil dari kombinasi terpilih. Kemudian alokasikan demaind dan supply sebanyak mungkin ke variabel dengan unit biaya terkecil dalam baris atau kolom yang dipilih. Kemudian sesuaikan penawaran dan permintaan dengan mencoret baris atau kolom kemudian diganti dengan nol. Jika baris atau kolom tidak menjadi nol, maka alokasikan ke unit biaya terkecil selanjutnya, pada baris atau kolom tersebut.

4. Memilih kandidat biaya terkecil dengan berikutnya dari kombinasi terpilih dan ulangi Langkah 3 sampai semua kolom dan baris habis.

\subsubsection{Modified Distribution (MODI)}

Modi adalah algoritma batu loncatan yang sudah diperhalus. Cara Modi menghitung indeks yang ditingkatkan ialah tanpa menggambarkan semua jejak tertutup. Jejak digambarkan sesudah ditemukan sel dengan indeks yang mempunyai harga negatif terbesar. Artinya, untuk dapat menentukan sel yang akan masuk ke dalam penyelesaian berikutnya seperti pada cara batu loncatan [7].

Menurut [6], Algoritma dari metode Modified Distribution (MODI) bisa dituliskan sebagai berikut :

1. Menentukan tabel awal yang fesibel dengan menggunakan metode ongkos terkecil.

2. Menambahkan variabel $U i$ dan $V j$ pada setiap baris atau kolom.

3. Mencari nilai $U i$ maupun $V j$ untuk setiap sel baris dengan menggunakan rumus: $U i+V j=C i j$ dengan memisahkan salah satu nilai $U i$ atau $V j$ sama dengan nol.

4. Menghitung semua nilai sel bukan basis dengan menggunakan rumus $C i j-U i-V J$. Menentukan sel yang akan masuk basis dengan memilih nilai sel bukan basis yang memiliki nilai sel negatif terbesar. Kemudian membuat closed path untuk menentukan sel yang akan keluar dengan memilih jumlah unit terkecil dari sel yang bertanda negatif.

5. Tabel optimum akan tercapai apabila sel bukan basis semuanya memiliki nilai $=0$

6. Jika tabel belum optimum, kembali ke Langkah 2 sehingga ditemukan tabel optimum. 


\subsection{Metode/Metodologi Penelitian}

Langkah-langkah yang digunakan dalam penelitian ini adalah sebagai berikut:

1. Pengumpulan data

Data ini penulis ambil dari Toko Empat Saudara yaitu data pendistribusian beras yang memiliki 4 sumber 5 tujuan. Data ini diambil dengan melakukan wawancara kepada pemilik toko dengan supply dan demmand seimbang.

2. Menyusun data yang diperoleh kedalam model transportasi.

3. Menyelesaikan model transportasi menggunakan Best Candidate Method

Adapun langkah-langkah Best Candidate Method:

a. Menyusun data ke tabel transportasi.

b. Periksa apakah tabel tersebut seimbang atau tidak seimbang. Jika tidak seimbang maka penambahan baris dummy atau kolom dummy.

c. Memilih dua kandidat kombinasi pertama dan kombinasi kedua.

d. Pengalokasian supply dan demand pada kombinasi pertama dan kedua sampai menjadi nol. Kemudian dapatlah hasil keduanya,dan hasil terkecil itulah biaya minimum yang didapatkan.

4. Uji optimalitas menggunakan Metode Modified Distribution (MODI). Setelah hasil MODI sama dengan hasil Best Candidate Method,maka nilai yang didapat sudah optimal.

5. Membuat kesimpulan.

\section{Hasil dan Pembahasan}

Toko Empat Saudara terdapat lima tujuan, yaitu, Pasir Pengaraian, Kualu dan Kubang, Cipta Karya, Rajawali, dan Arengka 2 dan Stadion. Masing-masing memiliki total permintaan yaitu: 300 karung, 250 karung, 200 karung, 150 karung dan 200 karung. Selanjutnya data alat transportasi dan muatan yaitu L300 (A) dengan muatan 300 karung, L300 (B) dengan muatan 300 karung, Grandmax (A) dengan muatan 250 karung dan Grandmax (B) dengan muatan 250 karung serta biaya transportasi pendistribusian beras. Berikut model transportasi Toko Empat Saudara yang dapat dilihat pada Tabel 1:

Tabel 1. Model Transportasi Toko Empat Saudara Pekanbaru

\begin{tabular}{|c|c|c|c|c|c|c|}
\hline \multirow[b]{2}{*}{$\begin{array}{c}\text { Alat } \\
\text { Trasnportasi }\end{array}$} & \multicolumn{5}{|c|}{ Tujuan } & \multirow[b]{2}{*}{ Supply } \\
\hline & $\begin{array}{c}\text { Ps. } \\
\text { Panggraian }\end{array}$ & $\begin{array}{l}\text { Kualu dan } \\
\text { Kubang }\end{array}$ & Cipta Karya & Rajawali & $\begin{array}{c}\text { Arengka } 2 \\
\text { dan Stadion }\end{array}$ & \\
\hline \multirow[t]{2}{*}{ L300 (A) } & 2333,33 & 500 & 400 & 166,66 & 333,33 & 300 \\
\hline & $X_{11}$ & $X_{12}$ & $X_{13}$ & $X_{14}$ & $X_{15}$ & \\
\hline \multirow[t]{2}{*}{ L300(B) } & 2333,33 & 500 & 400 & 166,66 & 333,33 & 300 \\
\hline & $X_{21}$ & $X_{22}$ & $X_{23}$ & $X_{24}$ & $X_{25}$ & \\
\hline \multirow{2}{*}{$\begin{array}{l}\text { Grandmax } \\
\text { (A) }\end{array}$} & 2400 & 400 & 400 & 200 & 400 & 250 \\
\hline & $X_{31}$ & $X_{32}$ & $X_{33}$ & $X_{34}$ & $X_{35}$ & \\
\hline \multirow{2}{*}{$\begin{array}{l}\text { Grandmax } \\
\text { (B) }\end{array}$} & 2400 & 400 & 400 & 200 & 400 & 250 \\
\hline & $X_{41}$ & $X_{42}$ & $X_{43}$ & $X_{44}$ & $X_{45}$ & \\
\hline Demand & 300 & 250 & 200 & 150 & 200 & 1100 \\
\hline
\end{tabular}

Berdasarkan Tabel 1, dapat dibuat model transportasi sebagai berikut: 
Minimum $Z=2333,33 X_{11}+500 X_{12}+400 X_{13}+166,66 X_{14}+333,33 X_{15}+2333,33 X_{21}+500 X_{22}$ $400 X_{23}+166,66 X_{24}+333,33 X_{25}+2400 X_{31}+400 X_{32}+400 X_{33}+$
$200 X_{34}+400 X_{35}+2400 X_{41}+400 X_{42}+400 X_{43}+200 X_{44}+400 X_{45}$

Kendala

Persediaan: $\quad X_{11}+X_{12}+X_{13}+X_{14}+X_{15}=300$

$X_{21}+X_{22}+X_{23}+X_{24}+X_{25}=300$

$X_{31}+X_{32}+X_{33}+X_{34}+X_{35}=250$

$X_{41}+X_{42}+X_{43}+X_{44}+X_{45}=250$

Permintaan: $\quad X_{11}+X_{21}+X_{31}+X_{41}+X_{51}=300$

$X_{12}+X_{22}+X_{32}+X_{42}+X_{52}=250$

$X_{13}+X_{23}+X_{33}+X_{43}+X_{53}=200$

$X_{14}+X_{24}+X_{34}+X_{44}+X_{54}=150$

$X_{15}+X_{25}+X_{35}+X_{45}+X_{55}=200$

dengan :

$X_{11}$ : Banyaknya beras yang didistribusikan menggunakan L300 (A) ke Pasir Pengaraian.

$X_{12}$ : Banyaknya beras yang didistribusikan menggunakan L300 (A) ke Kualu dan Kubang.

$X_{13}$ : Banyaknya beras yang didistribusikan menggunakan L300 (A) ke Cipta Karya.

$X_{14}$ : Banyaknya beras yang didistribusikan menggunakan L300 (A) ke Rajawali.

$X_{15}$ : Banyaknya beras yang didistribusikan menggunakan L300 (A) ke Arengka 2 dan

Stadion.

$X_{21}$ : Banyaknya beras yang didistribusikan menggunakan L300 (B) ke Pasir Pengaraian.

$X_{22}$ : Banyaknya beras yang didistribusikan menggunakan L300 (B) ke Kualu dan

Kubang.

$X_{23}$ : Banyaknya beras yang didistribusikan menggunakan L300 (B) ke Cipta Karya.

$X_{24}$ : Banyaknya beras yang didistribusikan menggunakan L300 (B) ke Rajawali.

$X_{25}$ : Banyaknya beras yang didistribusikan menggunakan L300(B) ke Arengka 2 dan Stadion.

$X_{31}$ : Banyaknya beras yang didistribusikan menggunakan Grandmax (A) ke Pasir Pengaraian.

$X_{32}$ : Banyaknya beras yang didistribusikan menggunakan Grandmax (A) ke Kualu dan Kubang.

$X_{33}$ : Banyaknya beras yang didistribusikan menggunakan Grandmax (A) ke Cipta Karya

$X_{34}$ : Banyaknya beras yang didistribusikan menggunakan Grandmax (A) ke Rajawali.

$X_{35}$ : Banyaknya beras yang didistribusikan menggunakan Grandmax (A) ke Arengka 2 dan Stadion.

$X_{41}$ : Banyaknya beras yang didistribusikan menggunakan Grandmax (B) ke Pasir Pengaraian.

$X_{42}$ : Banyaknya beras yang didistribusikan menggunakan Grandmax (B) ke Kualu dan Kubang.

$X_{43}$ : Banyaknya beras yang didistribusikan menggunakan Grandmax (B) ke Cipta Karya. 
$X_{44}$ : Banyaknya beras yang didistribusikan menggunakan Grandmax (B) ke Rajawali.

$X_{45}$ : Banyaknya beras yang didistribusikan menggunakan Grandmax (B) ke Arengka 2 dan Stadion.

a. Penyelesaian menggunakan Best Candidate Method

Langkah pertama, periksa kesetimbangan matriks, jika total supply sama dengan total demmand, maka matriks dikatakan seimbang dan dilanjutkan ke langkah kedua. Langkah kedua, memilih kandidat masing-masing baris dipilih dengan dua kandidat dengan dua ongkos terkecil pertama dan kedua. Jika terdapat kandidat yang sama nilainya lebih dari satu, maka pilih kandidat yang nilainya sama lebih dari satu tersebut. Berikut ini merupakan nilai kandidat dari Toko Beras Empat Saudara yang dapat dilihat pada Tabel 2:

Tabel 2. Menentukan Nilai Kandidat Toko Empat Saudara Pekanbaru

\begin{tabular}{lcccccc}
\hline Alat Transportasi & $\begin{array}{c}\text { Pasir } \\
\text { Pengaraian }\end{array}$ & $\begin{array}{c}\text { Kualu dan } \\
\text { Kubang }\end{array}$ & $\begin{array}{c}\text { Cipta } \\
\text { Karya }\end{array}$ & Rajawali & $\begin{array}{c}\text { Arengka 2 } \\
\text { dan Stadion }\end{array}$ & Supply \\
\hline L300 (A) & 2333,33 & 500 & 400 & 166,66 & 333,33 & 300 \\
\hline L300 (B) & 2333,33 & 500 & 400 & 166,66 & 333,33 & 300 \\
\hline Grandmax(A) & 2400 & 400 & 400 & 200 & 400 & 250 \\
\hline Grandmax(B) & 2400 & 400 & 400 & 200 & 400 & 250 \\
\hline Demand & 300 & 250 & 200 & 150 & 200 & 1100 \\
\hline
\end{tabular}

Selanjutnya, menentukan kombinasi dengan memilih satu baris satu kombinasi tetapi tidak boleh dengan kolom yang sama yang dapat dilihat pada Tabel 3 berikut:

Tabel 3. Kombinasi Pertama Toko Empat Saudara Pekanbaru

\begin{tabular}{lcccccc}
\hline $\begin{array}{c}\text { Alat } \\
\text { Transportasi }\end{array}$ & $\begin{array}{c}\text { Pasir } \\
\text { Pengaraian }\end{array}$ & $\begin{array}{c}\text { Kualu dan } \\
\text { Kubang }\end{array}$ & $\begin{array}{c}\text { Cipta } \\
\text { Karya }\end{array}$ & Rajawali & $\begin{array}{c}\text { Arengka 2 } \\
\text { dan Stadion }\end{array}$ & Supply \\
\hline L300 (A) & 2333,33 & 500 & 400 & 166,66 & 333,33 & 300 \\
\hline L300 (B) & 2333,33 & 500 & 400 & 166,66 & 333,33 & 300 \\
\hline Grandmax(A) & 2400 & 400 & 400 & 200 & 400 & 250 \\
\hline Grandmax(B) & 2400 & 400 & 400 & 200 & 400 & 250 \\
\hline Demand & 300 & 250 & 200 & 150 & 200 & 1100 \\
\hline
\end{tabular}

Setelah kombinasi pertama didapatkan, maka selanjutnya akan mencari kombinasi kedua dengan langkah yang sama untuk mendapatkan kombinasi kedua. Selanjutnya, Langkah ketiga, identifikasi baris-baris dengan nilai kandidat terkecil. Setelah itu alokasikan persediaan dan permintaan sebesar-besarnya pada kandidat tersebut, jika masih menyisakan nilai persediaan atau permintaan, alokasikan nilai persediaan atau permintaan tersebut ke unit ongkos terkecil selanjutnya pada baris yang terpilih seperti tabel berikut:

Tabel 4. Pengalokasian dimulai dari Kombinasi Pertama pada Nilai Kandidat di baris Pertama Toko Empat Saudara

\begin{tabular}{lcccccc}
\hline $\begin{array}{c}\text { Alat } \\
\text { Transportasi }\end{array}$ & $\begin{array}{c}\text { Pasir } \\
\text { Pengaraian }\end{array}$ & $\begin{array}{c}\text { Kualu dan } \\
\text { Kubang }\end{array}$ & $\begin{array}{c}\text { Cipta } \\
\text { Karya }\end{array}$ & Rajawali & $\begin{array}{c}\text { Arengka 2 } \\
\text { dan Stadion }\end{array}$ & Supply \\
\hline L300(A) & 2333,33 & 500 & 400 & $\begin{array}{c}150 \\
166,66\end{array}$ & $\begin{array}{c}150 \\
333,33\end{array}$ & 300 \\
\hline L300(B) & 2333,33 & 500 & 400 & 166,66 & 333,33 & 300 \\
\hline Grandmax(A) & 2400 & 400 & 400 & 200 & 400 & 250 \\
\hline Grandmax(B) & 2400 & 400 & 400 & 200 & 400 & 250 \\
\hline Demand & 300 & 250 & 200 & 150 & 200 & 1100 \\
\hline
\end{tabular}

Banyak permintaan pada kandidat di baris pertama lebih kecil dari pada nilai kapasitasnya, maka alokasikan nilai permintaannya ke kandidat terpilih tersebut. Dengan 
cara yang sama pengalokasian dilakukan sampai baris keempat. Pengalokasian berhenti apabila nilai permintaannya sudah teralokasikan semua di baris kedua, maka tidak ada lagi yang dialokasikan dikandidat baris keempat dan nilai persediaan dibaris keempat yang bersisa dialokasikan keongkos terkecil berikutnya. Sehingga semua supply dan demmand menjadi nol.

Tabel 5. Pengalokasikan Supply dan Demmand sampai Menjadi Nol pada Kombinasi Pertama Toko Empat Saudara

\begin{tabular}{|c|c|c|c|c|c|c|}
\hline Alat Transportasi & $\begin{array}{c}\text { Pasir } \\
\text { Pengaraian }\end{array}$ & $\begin{array}{c}\text { Kualu dan } \\
\text { Kubang }\end{array}$ & $\begin{array}{l}\text { Cipta } \\
\text { Karya }\end{array}$ & Rajawali & $\begin{array}{c}\text { Arengka } 2 \\
\text { dan Stadion }\end{array}$ & Supply \\
\hline L300(A) & 2333,33 & 500 & 400 & $\begin{array}{c}150 \\
166,66\end{array}$ & $\begin{array}{c}150 \\
333,33\end{array}$ & 0 \\
\hline L300(B) & 2333,33 & 500 & $\begin{array}{l}200 \\
400 \\
\end{array}$ & 166,66 & $\begin{array}{c}50 \\
333,33 \\
\end{array}$ & 0 \\
\hline Grandmax(A) & $\begin{array}{l}50 \\
2400\end{array}$ & $200 \quad 400$ & 400 & 200 & 400 & 0 \\
\hline Grandmax(B) & $\begin{array}{l}250 \\
2400 \\
\end{array}$ & 400 & 400 & 200 & 400 & 0 \\
\hline Demand & 0 & 0 & 0 & 0 & 0 & 1100 \\
\hline
\end{tabular}

Jadi, diperoleh nilai $Z$ pada kombinasi pertama, yaitu :

$$
\begin{aligned}
Z & =150(166,66)+150(333,33)+50(500)+200(400)+50(333,33)+50(2400) \\
& +200(400)+250(2400) \\
& =996.556
\end{aligned}
$$

Setelah didapatkannya komnbinasi pertama, maka akan mulai mencari kombinasi kedua dengan cara yang sama seperti kombinasi pertama, sehingga diperoleh tabel pengalokasian kombinasi kedua sebagai berikut :

\begin{tabular}{|c|c|c|c|c|c|c|}
\hline $\begin{array}{c}\text { Alat } \\
\text { Transportasi }\end{array}$ & $\begin{array}{c}\text { Pasir } \\
\text { Pengaraian }\end{array}$ & $\begin{array}{l}\text { Kualu dan } \\
\text { Kubang }\end{array}$ & $\begin{array}{l}\text { Cipta } \\
\text { Karya }\end{array}$ & Rajawali & $\begin{array}{c}\text { Arengka } 2 \\
\text { dan } \\
\text { Stadion }\end{array}$ & Supply \\
\hline L300(A) & 2333,33 & 500 & $\begin{array}{l}100 \\
400\end{array}$ & 166,66 & $\begin{array}{c}200 \\
333,33\end{array}$ & 0 \\
\hline L300(B) & 2333,33 & 500 & $\begin{array}{l}100 \\
400\end{array}$ & $\begin{array}{c}150 \\
166,66\end{array}$ & 333,33 & 0 \\
\hline Grandmax (A) & $\begin{array}{c}50 \\
2400\end{array}$ & $200 \quad 400$ & 400 & 200 & 400 & 0 \\
\hline Grandmax(B) & $\begin{array}{c}250 \\
2400\end{array}$ & 400 & 400 & 200 & 400 & 0 \\
\hline Demand & 0 & 0 & 0 & 0 & 0 & 1100 \\
\hline
\end{tabular}

Tabel 6. Pengalokasikan Supply dan Demmand sampai Menjadi Nol pada Kombinasi Kedua Toko Empat Saudara

Jadi diperoleh hasil nilai $Z$ pada kombinasi kedua, yaitu:

$$
\begin{aligned}
Z & =100(400)+200(2333,33)+50(500)+100(400)+150(166,66)+50(2400) \\
& +200(400)+250(2400) \\
& =996.665
\end{aligned}
$$

Setelah mendapatkan hasil kombinasi kedua dari solusi layak awal dengan Best Candidate Method, maka telah selesai mencari nilai $Z$ karena kandidat yang terpilih menghasilkan dua kombinasi. Kombinasi pertama menghasilkan solusi layak awal atau biaya transportasi sebesar Rp. 996.556. Sedangkan kombinasi kedua menghasilkan solusi layak awal atau biaya transportasi sebesar Rp. 996.665 
b. Penyelesaian Model Transportasi Toko Beras Empat Saudara menggunakan MODI Tabel 7. Model Transportasi Kombinasi Pertama Toko Empat Saudara

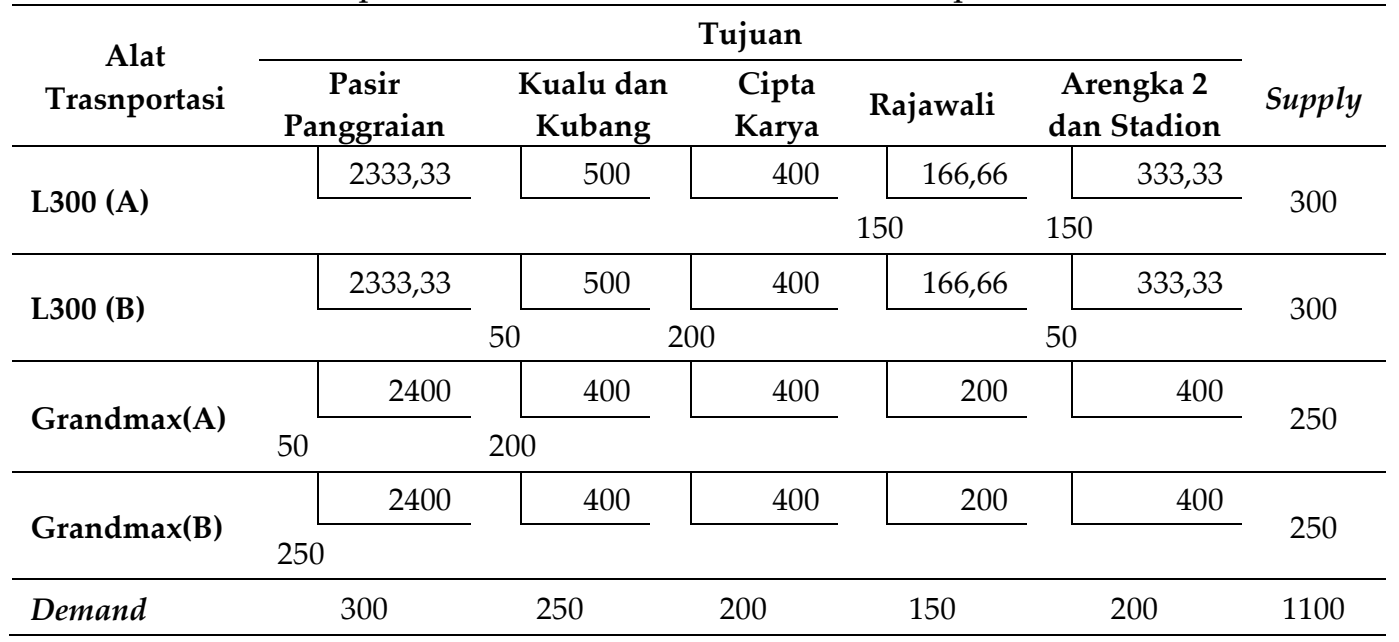

Jadi diperoleh hasil nilai $Z_{0}$ dari kombinasi pertama dari Best Candidate Method untuk MODI sebagai berikut:

$$
\begin{aligned}
Z_{0} & =150(166,66)+150(333,33)+50(500)+200(400)+50(333,33)+50(2400) \\
& +200(400)+250(2400) \\
= & 996.556
\end{aligned}
$$

Setelah dipilihnya kombinasi pertama menjadi model transportasinya, maka selanjutnya menghitung indeks baris dan kolom yang terisi untuk iterasi pertama dengan menggunakan rumus $U i+V j=C i j$. Setelah mendapatkan nilai indeks baris dan kolom yang terisi, selanjutnya akan menghitung indeks perubahan ongkos dan sel kosong untuk iterasi pertama dengan rumus $C i j-U i-V j$. Iterasi pertama belum optimal, karena masih ada $C i j$ yang bernilai negatif. Sehingga diperoleh hasil transportasi untuk iterasi pertama sebagai berikut:

Tabel 8. Hasil Transportasi Iterasi 1 menggunakan MODI

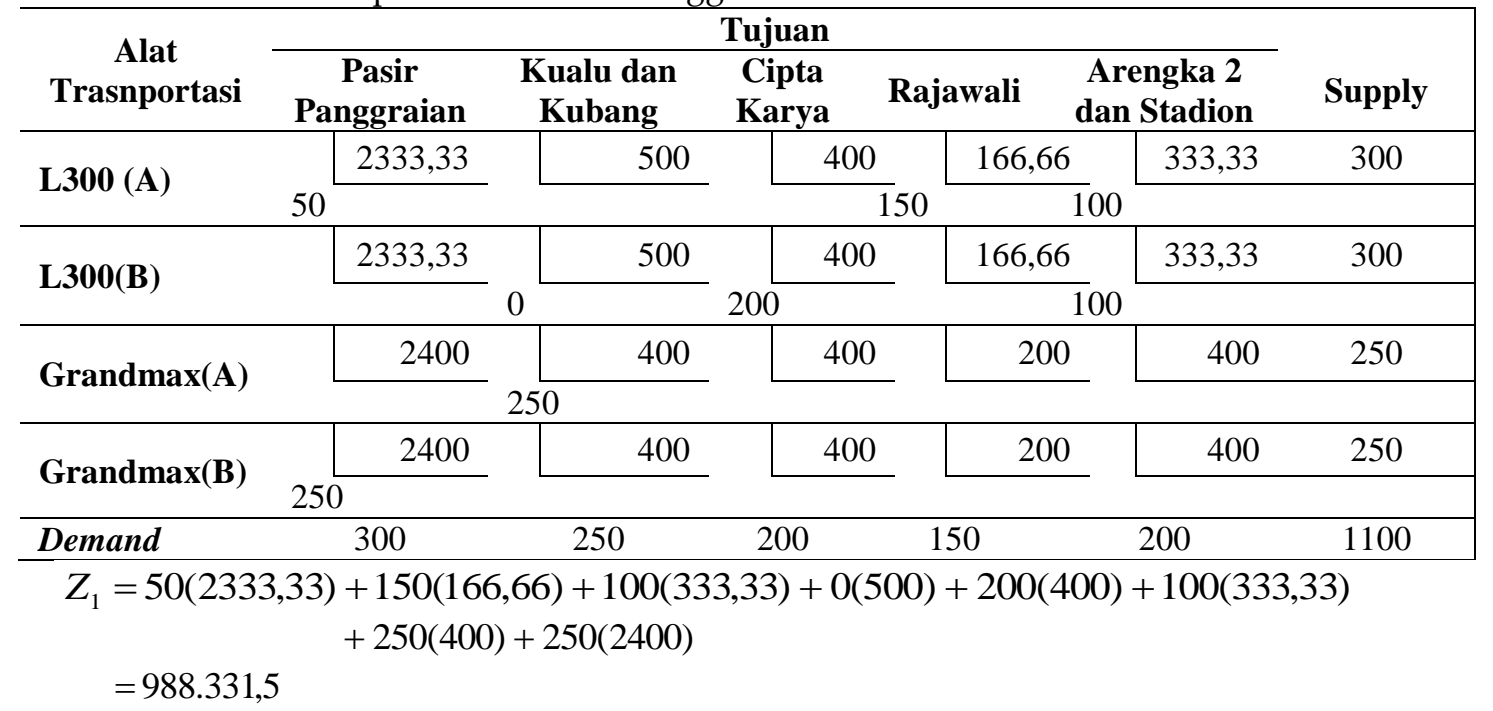

Solusi dikatakan optimal apabila nilai indeks perubahan ongkos iterasi ke delapan tidak ada nilai $C i j$ yang bernilai negatif. Solusi optimal diperoleh setelah melakukan iterasi sebanyak 8 kali. 
Tabel 9. Hasil Transportasi Iterasi 7

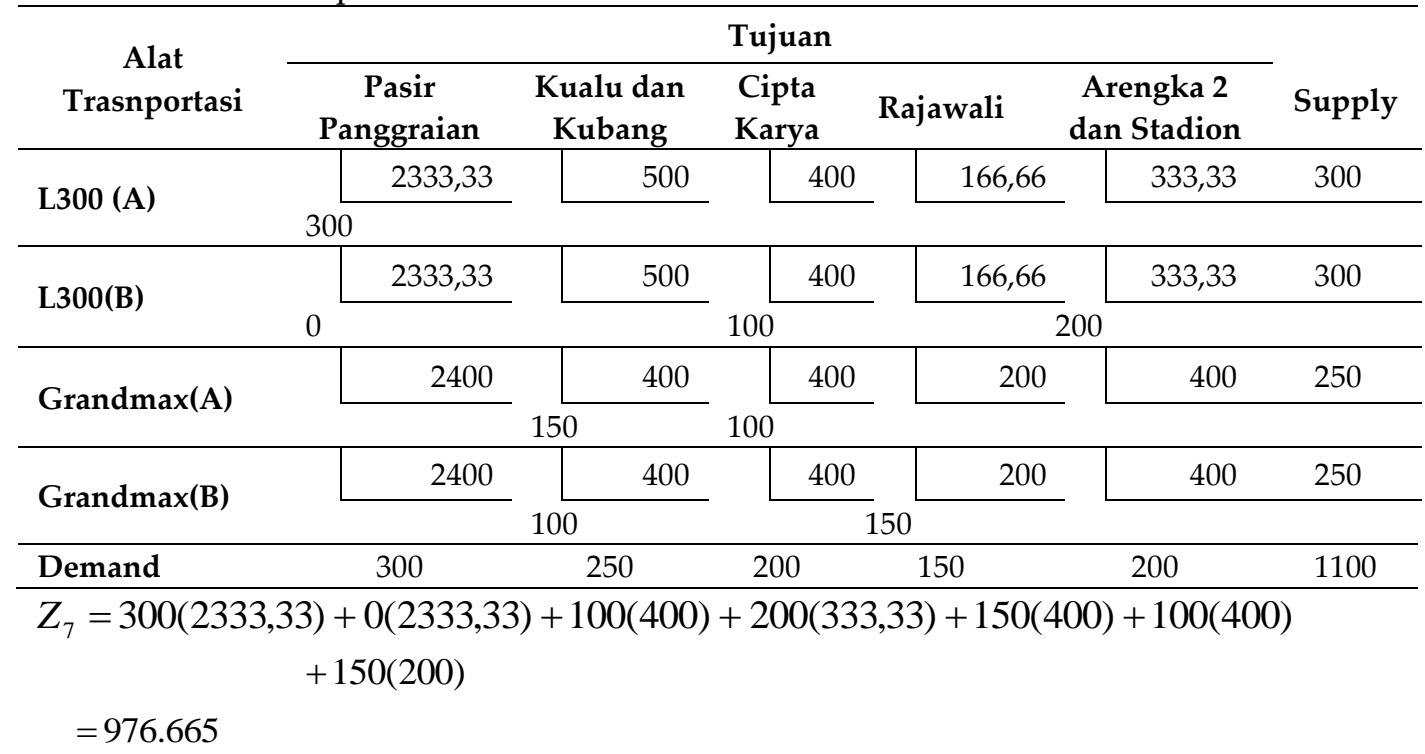

Berdasarkan Tabel 9 diperoleh $X_{11}=300, X_{21}=0, \quad X_{23}=100, X_{25}=200$, $X_{32}=150, \quad X_{33}=100, \quad X_{42}=100, \quad X_{44}=150$ sehingga diperoleh $Z=300(2333,33)$ $+0(2333,33)+100(400)+200(333,33)+150(400)+100(400)+100(400)+150(200)$ $=976.665$.

Selanjutnya, pendistribusian beras menggunakan L300(A) ke Pasir Pengaraian ( $\left.X_{11}\right)$ sebanyak 300 karung, L300 (B) ke Cipta Karya $\left(X_{23}\right)$ sebanyak 100 karung, L300(B) ke Arengka 2 dan Stadion $\left(X_{25}\right)$ sebanyak 200 karung, Grandmax(A) ke Kualu dan Kubang $\left(X_{32}\right)$ sebanyak 150 karung, Grandmax(A) ke Cipta Karya $\left(X_{33}\right)$ sebanyak 100 karung, Grandmax(B) ke Kualu dan Kubang $\left(X_{42}\right)$ sebanyak 100 karung, Grandmax(B) ke Rajawali $\left(X_{44}\right)$ sebanyak 150 karung, diuji dengan solusi optimal menggunakan Modified Distribution (MODI) diperoleh biaya yaitu Rp. 976.665.

\section{Kesimpulan}

Berdasarkan hasil dari penelitian, penyelesaian masalah pendistribusian beras Toko Empat Saudara Pekanbaru menggunakan Best Candidate Method menghasilkan L300 (A) ke Rajawali sebanyak 150 karung, L300 (A) ke Arengka 2 dan Stadion sebanyak 150 karung, L300 (B) ke Kualu dan Kubang sebanyak 50 karung, L300 (B) ke Cipta Karya sebanyak 200 karung, L300 (B) ke Arengka 2 dan Stadion sebanyak 50 karung, Grandmax (A) ke Pasir Pengaraian sebanyak 50 karung, Grandmax (A) ke Kualu dan Kubang sebanyak 200 karung, Grandmax (B) ke Pasir Pengaraian sebanyak 250 karung dengan biaya transportasi sebesar Rp. 996.566 dan menggunakan MODI menghasilkan L300 (A) ke Pasir Pengaraian sebanyak 300 karung, L300 (B) ke Arengka 2 dan Stadion sebanyak 200 karung, Grandmax (A) ke Kualu dan Kubang sebanyak150 karung, Grandmax (A) ke Cipta Karya sebanyak 100 karung, Grandmax (B) ke Kualu dan Kubang sebanyak 100 karung, Grandmax (B) ke Rajawali sebanyak 150 karung dengan biaya pendistribusian sebesar Rp. 976.665. 


\section{DAFTAR PUSTAKA}

[1] D. Matematika, F. Matematika, D. A. N. Ilmu, P. Alam, and U. S. Utara, "Analisis Penerapan Model Transportasi Dengan Metode Vogel Approximation (Vam) Dengan Uji Modified Distribution (Modi) Analisis Penerapan Model Transportasi Dengan Metode Vogel Approximation (Vam) Dengan Uji Modified Distribution (Modi)," 2019.

[2] M. Metode and V. S. Approximation, "Analisis Perbandingan Pengiriman Barang Menggunakan Metode Vogel's Approximation Method (Vam) Dan Modified Distribution (Modi) (Studi Kasus: Pt. Coca Cola Amatil Indonesia Surabaya)," JURTEKSI, vol. V, no. 1, pp. 51-58, 2018.

[3] N. K. Kertiasih, "Penggunaan Metode Transportasi Dalam Program Linier Untuk Pendistribusian Barang," UNDIKSHA, vol. 6, no. 2, pp. 27-35, 2009.

[4] Y. Haryono, "Penyelesaian Masalah Model Transportasi Dengan Menggunakan Metode Simpleks Transportasi," vol. I, no. 2, pp. 71-77, 2015.

[5] I. N. Amin, "Identifikasi Alternatif Pengadaan Bahan Baku Di Perusahaan Daerah Air Minum (Pdam) Kabupaten Boyolali,” Muhammadiyah Surakarta, 2007.

[6] Siswanto, Operation Research Jilid 1. Jakarta: Erlangga, 2007.

[7] H. A. Ahmad and P. O. B. Amman, "The Best Candidates Methods For Solving Optimization Problem,” J. Comput. Sci., vol. 8, no. 5, pp. 711-715, 2012.

[8] E. R. B. Wulan, "Penggunaan Best Candidate Method Untuk Mendapatkan Solusi Layak Awal Masalah Transportasi," Mercumatika, vol. 1, no. 2, pp. 113-118, 2017.

[9] P. T. G. Makassar, "Implementasi metode transportasi dalam optimasi biaya distribusi roti pada pt. granedia makassar," Teknosains, vol. 11, no. 1, pp. 135-148, 2017. 